2020, Volume 10, International Conference Globalization, Innovation and Development. Trends and Prospects (G.I.D.T.P.), pages: $44-50$ | https://doi.org/10.18662/lumproc/gidtp2018/06

\section{The Importance of Management and Communication in School Units}

\section{Timeea-Alexandra D. SIMIONESCU (SAVU), Doina TODORUT' ${ }^{2}$}

${ }^{1} \mathrm{PhD}$ student University of 'Valahia', Romania, Targoviste, alexa timeea@yahoo.com

${ }^{2} \mathrm{PhD}$ student University of 'Valahia', Romania, Targoviste, todorut_doina@yahoo.com
Abstract: The purpose of this article is to recognize the importance of communication in the management of the school organization, being in a continuous changing. The need to adjust at this changings of the entire educational system, and also of the school organization, represents a topical subject of the research in the literature. Leadership is now an attribute desired/ demanded also by the school organization, to their directors. In this context, the leaders have self-confidence generating trust to others. Around true leaders, employees feel prepared, appreciated and work with enthusiasm. Leadership is connected with the power to influence the human's behavior. The way to determine the human resources to understand the need of changing, can be implemented only by means of a leader, who appreciate and understand the need for adjust and change, use an optimal process of communication, generating unity in making decisions.

Keywords: Management; leader; communication; decisions; school performance.

How to cite: Simionescu (Savu), T.-A. D., \& Todorut, D. (2020). The Importance of Management and Communication in School Units. In I. Panagoreț \& G. Gorghiu (vol. ed.), Lumen Proceedings: Vol. 10. International Conference Globalization, Innovation and Development. Trends and Prospects (G.I.D.T.P.) (pp. 44-50). Iasi, Romania: LUMEN Publishing House. https://doi.org/10.18662/lumproc/gidtp2018/06 


\section{Introduction}

The educational management aims to achieve the strategic and operational objectives of the school institution, fulfilling the mission of the school, expression of vision, ethos and organizational culture. The director of a school unit in a turbulent environment, where change is happening more and more rapidly, calls for a complex competency profile. Directors should be the promoters of changing in education, which requires them a remarkable attachment to school and to the values of education.

The managers positions are those people who have the authority to make decisions by which resources are employed, in order to achieve goals. Decision making can be intuitive, even arbitrary, or, on the contrary, based on knowledge, ideas, rules, principles, and experience. Those who act as managers say there is "no single way to drive - as a pattern."

There are many influences in the work of specific managers and requirements about the skills needed to be able to conduct such leadership activity. Therefore, the difference between of those who are led by them.

\section{Theoretical Background}

There are five leadership styles: authoritarian-oppressive, authoritarian-objective, democratic-consultative, participatory-democratic, laissez-faire, each with specific features, strengths and weaknesses; but a good leader can combine elements of different styles in his own activity according to his personality and the need to adapt to the changes that are required at one time [5].

According to E. Ghiselli, the most important features of successful managers' personalities are the following: the ability to supervise, the need for occupational fulfillment, intelligence and self-actualization. Qualities that the director has to demonstrate in practice in various situations where he / she has to orient his / her behavior towards people, to support the employees in their efforts, considering him / her more effective than a behavior focused on the accomplishment of the tasks [6].

Thus, it balances its concerns by focusing on the two directions (people and goals). However, it can also be said that each style of driving has its effectiveness, but within each style there are disadvantages or shortcomings [3]. 


\section{Argument of the paper}

Different methods and tools are needed to better understand the scientific research process.

The research is based on a remark and also a question that requires a separate analysis: "What's the significance of the term leadership and what implications this title implies?" This question is quite comprehensive and refers to the professional reasoning and judgements, but also the decisionmaker. It is imperative to find out the origin and functionality of the concept of leader (not only theoretical but also practical), to facilitate understanding the multitude of meanings [7].

\section{Arguments to support the thesis}

The research presents an analysis for understanding the management phenomenon by using an efficient communication and starts by defining elements such as management, manager, leader and leadership, characteristics, attributions; elements that help to define and explain this topical phenomenon of the overwhelming importance that distinguishes between success and failure.

\section{Arguments to argue the thesis}

The driving style must be adapted to the "age" and the characteristics of the working group.

Thus, we can consider two styles: task oriented (the leader has the capacity to cognitively define the situation, to establish and formulate credible objectives, to synthesize the problems that arise during the work process); and oriented towards relationships (the leader is a binder for informal employee groups, is a key factor in preventing potential conflicts).

In this context, Blanchard and Hersey suggest that the agreement between leadership style and the needs of the group is determined by the degree of maturity of that group. Thus, members of an immature group will have better results with a task-oriented leader. As the group matures, the leader can adopt a style characterized by both directions simultaneously. In middle-aged groups, relationship oriented style is more effective, while for "aging" groups the laissez-faire style (or low score style in both orientations) is the most appropriate. Therefore, during the lifetime of a work group, it is advisable for the leader to adopt four successive leadership styles, 
characterized by the terms: communication, persuasion, participation and delegation [4].

The effective relationship of the school manager in or outside the educational environment is guaranteed by the development and ability to use the following skills in solving problems:

- Communication and networking skills

- Psycho-social skills

- Competences in the use of information technologies

- Leadership / coordination and organization skills

- Assessment skills

- Resource management and management skills

- Competencies for institutional development

- Competences that aim at self-management.

Management consists, above all, in the realization, with the help of the communication, of a process of interpersonal influence exerted in a certain situation and aimed to achieve or fulfill objectives. To lead and organize an institution means to communicate, first and foremost to convey ideas, feelings, and decisions of subordinates and the possibility of returning information [8].

Communication is based on the information system - all data, figures, information, circuits and information flows, processes and means of information processing. The communication process determines greater efficiency, especially when the school principal attaches importance to his message and purpose. The information system comprises several elements: the data, the information, the circuit and the information flow, the means of information processing.

Managerial communication is defined as a form of inter-human communication, a management tool through which the manager can exercise his / her duties; communication means almost everything in management, whether it is formal, informal or non-formal communication [9].

An important role is played by the flow, according to the frequency which they transmit the information. It can be permanent - when information is transmitted daily, or periodically - when it reflects certain segments of the management process, generated by new emergencies, unforeseen.

The flow of information concerns the four main elements of the communication process: the issuer, the person who generates the information; the second element is the material to be transmitted, the communiqué, the information itself; the third element is transmission means 
and procedures; a fourth element being the recipient, that is, the one who must receive the information.

The exchange of information between the issuer and the recipient also takes several steps:

- The formation (birth) of the idea

- Ciphering and choosing the transmission process

- Transmission

- Reception and decipherment.

In each of the listed stages there are also situations that make it difficult to exchange information, such as antipathies, perceptions - in this case, the person receiving the information is influenced by the state he has at that time, by the grievances generated by his perception of the person in leadership, health, the environment in which the message is transmitted, the message. It is visible that the school manager spends a lot of time interacting, researching, controlling, in order to be able to manage the situation correctly and make the right decisions. There are also unforeseen situations, characterized by obstacles, barriers, which will require a manageable handling of things, a capacity to adapt to the newly created situation. The ability of nonverbal communication increases with age, with experience. Lack of feedback generates problems in the communication process.

Any activity in the school unit, ranging from routine activities to the most special activities undertaken, cannot be placed outside the communication process.

Communication is a complex of actions that have as a common element the transmission of information within the emitter-receiver relationship with the purpose of determining changes in individual or group behaviour.

For the manager, the different perception of those around us is an obstacle that can be diminished or eliminated by the action of knowing and understanding people so that situations in which communication is distorted and concretized into conflicts, which is the benefit of life, can be overcome.

As regards non-verbal communication and its importance, it has been proven by Albert Mehrabian in 1967 stating that 5\% of all the information communicated would be verbally communicated, about 40 percent through the voice message and 55\% through the bodily movements [1].

Communication has been defined as a particular form of exchange relationship between two or more people, two or more groups.

Essential for the act of communication are: 
- The relationship between individuals or groups

- Exchange, transmission and reception of meanings

- Voluntary or unintended behaviour of employees [9].

\section{Dismantling the arguments against}

Communication is a fundamental feature of existence.

That's why a good manager uses new methods of communication that doesn't limits the transmission and the univocal reception of messages, thus circulating on a unique channel and referring to a passive receiver. $\mathrm{He}$ must take into account the continuity of communication despite differences, individual differences in the use of communication codes, the role of opinions and attitudes in the communication process, the importance of the social and cultural context of exchange, especially in the case of mass communication [2].

Communication involves a set of interactions that shape social reality, because communication appears as access to one's subjectivity, to his intentions.

\section{Conclusions}

The strategy of determining human resources to understand the need for change can only be implemented through the a leader who appreciates and understands the need for adaptation and change, implicitly by using an optimal communication process, thus giving the teachers the awareness of personal involvement and unity in making decisions, the final goal being the wellbeing to school to get the performance.

The manager is, in essence, the binder, the catalyst, the force that drives the change, the coordination and the control in an organization. His task is to create an environment in which the activity is oriented so that members contribute to the goals of the group with the lowest volume of available resources such as money, time, effort, discomfort and material.

Although many directors have undergone specific training, management education cannot yet speak of a professionalization of the director position for individual or system reasons. Managerial training for executives, the need for continuous training, and a well-articulated policy of managerial selection and training are needed, given the global trend towards professionalization of school managers. Alongside the theoretical training, there should also be practical training that could be achieved by attending 
training sessions in institutions where professional and efficient management is practiced.

\section{References}

[1] Corniţă G. Comunicare şi semnificare. Studiul mimicii. Perspective multidisciplinare. ediția a 2a revizuită. Baia Mare: Editura Universității de Nord; 2006: 32.

[2] Cotoară D. Modele ale comunicării, Studii de Biblioteconomie şi Ştiințta informării/Library and Information Science Research. 2003; 7: 104.

[3] Davis K. Human Relations at Work. N.Y.: Mc Graw-Hill; 1967: 96.

[4] Hersey P., Blanchard K.H., Johnson D.E. Management of Organisational Behaviour Leading Human Resources, 8th ed. New Jersey: Prentice Hall; 2001: 9.

[5] Mescon M, Albert M, Khedouri F. Management. N.Y: Third Edition HarperRow, Publishers; 1988: 464.

[6] Russu C. Managementul IMM-urilor. Bucureşti: Editura Expert; 1996: 323.

[7] Vagu P, Stegăroiu I. Lideriatul - de la teorie la practică. Târgovişte: Editura Bibliotheca; 2006: 6-7.

[8] Miron CV. Comunicarea didactică şi managerială în şcoală. Studiu de caz în unitatea şcolară Alexandru Macedonski, Melineşti, Dolj; 2010. Available from: http://www.asociatia-profesorilor.ro/comunicarea-didactica-si-manageriala-inscoala-studiu-de-caz.html

[9] https://www.didactic.ro/materiale-didactice/importanta-comunicarii-insituatiile-de-criza 